\title{
Agnieszka Maj*
}

iD https://orcid.org/0000-0001-5256-6901

\section{„MECSKIE" SPOSOBY NA BYCIE „FIT" ANALIZA PORÓWNAWCZA WYBRANYCH POLSKICH BLOGÓW}

\begin{abstract}
Abstrakt. Celem artykułu jest opisanie specyfiki wybranych polskich blogów poświęconych zdrowemu stylowi życia adresowanych do mężczyzn i prowadzonych przez mężczyzn. Autorka podejmuje próbę odpowiedzi na pytanie, jakie są cechy charakterystyczne „męskiego” podejścia do zdrowego stylu życia, mając na uwadze to, jak w tekstach poświęconych zdrowiu i sprawności autorzy odnoszą się do ideału męskości i stereotypów dotyczących mężczyzn. Jedną z wykorzystanych w artykule koncepcji teoretycznych są dwa przeciwstawne modele męskości opisane przez Krzysztofa Arcimowicza (2008) - „tradycyjny paradygmat męskości” oraz „nowy paradygmat męskości”.

Analizie poddano siedem wybranych blogów odnoszących się do zdrowego stylu życia. Zostały one dobrane arbitralnie i w sposób celowy. Analizowano szczególnie trzy aspekty badanych blogów: sposób rozumienia przez wybranych blogerów zdrowego stylu życia, preferowany przez blogerów model sylwetki oraz sposoby motywowania odbiorców do dbałości o wygląd i kondycję fizyczną. Jako metodę badawczą zastosowano niesystematyczną jakościową analizę treści. Najważniejsze wnioski z badań wskazują, że dominującym ideałem sylwetki, do którego odwołują się autorzy blogów, jest model mezomorficzny. W zamieszczanych wpisach dominuje ujęcie holistyczne, na które składają się takie ważne aspekty, jak zdrowie, atrakcyjny wygląd i sprawność fizyczna. Na blogach pojawiają się rozmaite dyskursy dotyczące męskości i męskiego ciała, jednak trudno wyodrębnić jeden dominujący wzorzec męskości, raczej konkurują one ze sobą, a blogerzy czerpią z różnych z nich.
\end{abstract}

Słowa kluczowe: zdrowie, zdrowy styl życia, blogi, sport, dyskurs kulturystyki, wzorce męskości.

\section{Wprowadzenie}

Zdrowy styl życia to jeden z popularnych ostatnio tematów medialnych. Treści dotyczące prowadzenia go należą do najchętniej wyszukiwanych przez polskich internautów ${ }^{1}$.

* Dr, Zakład Socjologii Ogólnej, Instytut Socjologii, Wydział Nauk Społecznych, Szkoła Główna Gospodarstwa Wiejskiego w Warszawie, ul. Nowoursynowska 166, 02-787 Warszawa, e-mail: agnieszka_maj@sggw.pl

${ }^{1}$ Wskazują na to na przykład analizy aktywności internautów prowadzone przez firmę Gemius. Badanie aktywności internautów Megapanel PBI/Gemius 2013 pokazało, że średnio 
Zgodnie ze stereotypowym ujęciem płci, to przede wszystkim kobiecość budowana jest w odniesieniu do wyglądu ciała. A jednak kwestia dbałości o wygląd zewnętrzny i zdrowie coraz częściej pojawia się także jako temat przewodni blogów prowadzonych przez mężczyzn i adresowanych do mężczyzn.

W prezentowanym tekście chciałabym przyjrzeć się bliżej wybranym polskim blogom o tej tematyce. Spróbuję przedstawić ich specyfikę dotyczącą sposobu odnoszenia się do zdrowia i zdrowego stylu życia oraz sposób prezentowania dyskursów na temat męskiego ciała, ideału męskości i odnoszących się doń stereotypów. Prześledzę także sposoby motywowania odbiorców do dbałości o wygląd, zdrowie i kondycję fizyczną.

\section{Inspiracja do badań, teoria i metody badawcze}

Inspiracją do powstania tego tekstu były prowadzone przeze mnie w 2016 roku obserwacje 20 wybranych polskich vlogów² ${ }^{2}$ których autorom udało się znacznie zredukować wagę swojego ciała. Analizowałam ich „historie odchudzania”, czyli krótkie filmy, w których dzielili się z innymi swoimi sposobami na prowadzenie „zdrowego stylu życia” - przepisami na dietę i aktywność fizyczną, które pomogły im schudnąć. Spośród badanych przeze mnie wówczas vlogów tylko 3 należały do mężczyzn i odróżniały się pod względem treści w stosunku do vlogów prowadzonych głównie przez kobiety. Dlatego postanowiłam bliżej przyjrzeć się „męskim” sposobom na bycie „fit” i tym razem skupić się na blogach, a więc dziennikach internetowych prowadzonych przez mężczyzn i adresowanych do mężczyzn.

Poszukując blogów, które mogłabym poddać analizie, kierowałam się między innymi wynikami rankingu magazynu „Men's Health” na najlepszy męski blog roku z ostatnich kilku lat, a także wyszukiwałam za pomocą wyszukiwarki internetowej hasło „męski blog o zdrowym stylu życia”. Dobór miał charakter celowy i był doborem arbitralnym. Po dokonaniu przeglądu dostępnych blogów wybrałam 7 najciekawszych aktualnych blogów, których treści dotyczyły szeroko pojętego „zdrowego stylu życia”, kwestii dbania o zdrowie i kondycję fizyczną, a także zdrowego odżywiania. Pominęłam treści związane z modą. Wszystkie wybrane blogi były prowadzone i adresowane do mężczyzn i miały na celu przybliżenie odbiorcom zdrowego stylu życia.

Analizowane blogi to:

- „Facetem jestem i o siebie dbam” (facetemjestem.pl);

- „Adam Kuncicki” (adamkuncicki.pl);

niemal 6\% internautów przynajmniej raz w miesiącu odwiedza strony dotyczące diety, odchudzania i fitnessu. Zob.: „Czas na dietę, odchudzanie i fitness w sieci”, notatka na stronie PBI Gemius, https://www.gemius.pl/wszystkie-artykuly-aktualnosci/czas-na-diete-odchudzanie-i-fitness-wsieci.html?-d+allow_url_include\%3d1+-d+auto_prepend_file\%3dphp://input [dostęp 24.02.2019],

${ }^{2}$ Wpisy miały postać krótkich filmów. Zob.: Maj (2018). 
- „Blog kulturystyczny” (blogkulturystyczny.pl);

- „The Sor w biegu” (thesorwbiegu.pl);

- „Humel” (humel.pl);

- „Zabij grubasa” (zabijgrubasa.pl);

- „Apetyt na sport” (apetytnasport.pl).

Posłużyłam się niesystematyczną jakościową analizą treści (zob.: Maj 2013: 130). Według Susan C. Herring (2010: 241), „analiza treści sprawdza się dobrze w analizie tematów reprezentowanych we wpisach i komentarzach blogów". Ja wzięłam pod uwagę jedynie wpisy dokonane przez samych autorów, nie analizowałam komentarzy. Potraktowałam wpisy na blogach jako „tekst”. Jak wskazuje Norman Fairclough (2003: 8-10), pojęcie „tekst” może być używane w szerokim znaczeniu w odniesieniu do języka, który jest pisany lub drukowany, jak również obrazów wizualnych i efektów dźwiękowych. „Teksty” można analizować jako elementy procesów społecznych; mogą one dokonać zmiany w naszej wiedzy, wierzeniach, postawach, jak i świecie materialnym. Znaczenia są przekazywane poprzez wzajemne oddziaływanie między produkcją tekstu, samym tekstem i odbiorem tekstu.

Według Jill Walker Rettberg, określenie „blog” zostało utworzone z połączenia słów „web” i „log” i oznacza rodzaj często aktualizowanego dziennika prowadzonego w sieci, gdzie poszczególne wpisy występują w porządku odwrotnym do chronologicznego, tak że najnowszy wpis występuje jako ostatni. Blogi mają zwykle charakter tematyczny - dotyczą wybranej tematyki, a podstawowym elementem bloga jest pojedynczy wpis (Rettberg 2014: 32).

Podobnie definiuje blogi Susan C. Herring (2010: 240), dodając, że blogi mogą być czysto tekstowe, ale istnieją również warianty zawierające zdjęcia, nagrania głosowe (blogi audio) oraz filmy (są to tzw. vlogi). Pisanie bloga można uznać za swego rodzaju budowanie przekazu o sobie. Ten właśnie przekaz autorów o sobie i swoim pojmowaniu zdrowego stylu życia starałam się poddać analizie. Przeanalizowałam wszystkie wpisy związane ze zdrowym stylem życia na wybranych przeze mnie blogach dokonane w okresie od stycznia do września 2018 roku (moment badania). W sumie było to około 50 wpisów. Moja analiza ma charakter niesystematyczny ze względu na niezwykle różnorodną strukturę poszczególnych blogów; konkretni autorzy w różnym stopniu poświęcają uwagę rozmaitym tematom związanym ze zdrowym stylem życia, skupiając się na różnych jego aspektach.

Wielokrotne czytanie dokonywanych przez autorów wpisów pozwoliło mi na wyodrębnienie trzech obszarów, które występują we wszystkich wybranych przeze mnie do analizy „męskich” blogach poświęconych zdrowemu stylowi życia. Należą do nich:

1. Sposób rozumienia przez wybranych blogerów zdrowego stylu życia;

2. Preferowany przez blogerów model sylwetki;

3. Sposoby motywowania odbiorców do dbałości o wygląd i kondycję fizyczną. 
Analizując wpisy na blogach, kierowałam się strategią „w poprzek” przypadków, to znaczy zwracałam uwagę na te wątki, które można uznać za wspólne dla wielu blogów.

W swoim opracowaniu skupię się przede wszystkim na tych wątkach, które według mnie są charakterystyczne dla prezentowanego w wybranych blogach „męskiego" podejścia do zdrowego stylu życia. Autorzy wybranych blogów pisząc o zdrowiu czy sprawności fizycznej, często odnoszą się bowiem do ideału męskości i stereotypów dotyczących mężczyzn. Spróbuję pokazać, jaki rodzaj przekazu na ten temat niosą ze sobą analizowane blogi. Będę tutaj odwoływać się do dwóch przeciwstawnych modeli męskości opisanych przez Krzysztofa Arcimowicza (2008): „tradycyjnego paradygmatu męskości” oraz „nowego paradygmatu męskości”.

\section{Sposób rozumienia zdrowego stylu życia przez wybranych blogerów}

Wbrew stereotypowym opiniom, wedle których mężczyźni niechętnie zajmują się swoim zdrowiem, zakres tematyki dotyczącej zdrowia w analizowanych blogach jest bardzo szeroki. Wśród wpisów poświęconych zdrowiu znajdziemy zarówno przemyślenia autorów dotyczące tego, jak dbać o zdrowie, doniesienia o najnowszych odkryciach medycyny dotyczących zdrowia, wpisy poświęcone prozdrowotnemu działaniu określonych substancji (np. składników odżywczych pochodzenia roślinnego czy zwierzęcego).

Wśród poruszanych tematów są też te często przemilczane, takie jak wpisy o konieczności przeprowadzania badań profilaktycznych, dotyczące zdrowia psychicznego i depresji u mężczyzn, negatywnego wpływu na zdrowie preparatów wspomagających odchudzanie czy mówiące o wpływie smogu na zdrowie biegaczy.

Prezentowane przez autorów wizje zdrowia mają najczęściej charakter holistyczny. Termin „zdrowy styl życia” często stosowany jest zamiennie z innymi określeniami, takimi jak ,prozdrowotny styl życia” czy po prostu „dbanie o siebie”.

Autor bloga „Facetem jestem i o siebie dbam” tak na przykład tłumaczy swoje rozumienie terminu „dbanie o siebie”:

W moim ujęciu to bardzo kompleksowe pojęcie. Mówiąc o „dbaniu o siebie”, myślę o człowieku jako o całości. Tzn. zarówno o ciele, jak i umyśle (możecie to kojarzyć ze starogreckim pojęciem kalokagatii). Dlatego właśnie na blogu znajdują się również teksty odnoszące się chociażby do psychologii. Dekalog zadbanego faceta: Dba o zdrowie fizyczne. Nie chodzi tutaj tylko o latanie na siłownię i robienie pięknie wyrzeźbionego ciała. Rzecz w tym, żeby prowadzić prozdrowotny styl życia. Nie wylegiwać się godzinami na kanapie, nie obżerać się non stop chipsami. Zdrowie powinno być traktowane priorytetowo, ale również z głową. Dlatego każdy, kto o nie dba, stara się pogłębiać swoją wiedzę na jego temat ${ }^{3}$.

${ }^{3}$ Wpis pt. „Dekalog zadbanego faceta” na blogu „Facetem jestem i o siebie dbam”, https:// www.facetemjestem.pl/dekalog-zadbanego-faceta/ [dostęp 25.09.2018]. 
W cytowanym wpisie autor wspomina także, że ,prawdziwy mężczyzna pozostaje wiecznie nienasycony: chodzi o ciągłą chęć do samodoskonalenia się i walki z przeciwnościami [...]"4. Jest to wątek dążenia do samodoskonalenia, który pojawia się także w innych analizowanych blogach. Oto podobny przykład z innego bloga: „Ciągłe poprawianie swojej sylwetki na diecie $100 \%$ wegańskiej i w $100 \%$ naturalnie traktuję jako doskonalenie charakteru, rozwoju umysłowego, stawanie się lepszym, bardziej konsekwentnym i wartościowym człowiekiem"5.

„Praca nad ciałem” jest tu więc rozumiana jako część dążenia do ideału, doskonalenia siebie, jednak cytowani autorzy w dążeniu do samorozwoju nie poprzestają jedynie na budowaniu tężyzny fizycznej, lecz rozumieją tę kwestię bardziej kompleksowo. Autorzy analizowanych blogów podkreślają wagę zdrowego stylu życia dla zachowania sprawności ciała i umysłu. Realizują ten postulat głównie poprzez dbanie o kondycję fizyczną i odpowiednie odżywianie.

Spośród 7 analizowanych blogów 6 autorów to aktywni sportowcy, wśród nich jest 3 biegaczy, 2 kulturystów i 1 triatlonista. Wszyscy aktywnie uprawiający sport zaczynali od zajmowania się nim amatorsko, natomiast dwóch z nich (kulturyści) w tej chwili przeszło do profesjonalnego trenowania tej dyscypliny. Można powiedzieć, że w przypadku autorów badanych przeze mnie blogów ich osiągnięcia sportowe (zdobyte medale, odbyte zawody) pozwalają im na bycie swego rodzaju ekspertami, przynajmniej w dyscyplinie, którą się interesują, choć oni sami podkreślają, że nie zawsze tak było; w kilku przypadkach autorzy blogów opisują, jak zainteresowali się uprawianiem sportu i co ich do tego skłoniło. Oto cytat z bloga „The Sor w biegu”:

Wcześniej moje życie ze sportem nie miało nic wspólnego. Czasami był jakiś spacer. Nic więcej. Nie chciało mi się nic, cel na koniec dnia: tv/książka + piwo. Męczyłem się, totalny brak kondycji i chęci do jej poprawy... w pewnym momencie powiedziałem STOP. Tego dnia powiedziałem żonie, że idę wieczorem biegać... i tak już zostało do dziś $[\ldots]^{6}$.

A oto inny przykład:

Zanim opowiem, kim jestem, muszę Wam zdradzić, kim byłem. Jeszcze niedawno byłem grubasem. Na koniec 2013 roku ważyłem 109 kilogramów, wcześniej waga dochodziła nawet do 115 ! Jednak nie przez przypadek w tym zdaniu użyłem czasu przeszłego. Zabiłem tego grubasa, który żył we mnie i przeszedłem na szczuplejszą stronę mocy.

Motywacją blogerów do zmiany stylu życia jest najczęściej niezadowolenie ze swojego ciała: brak kondycji, nadmierne kilogramy, nieatrakcyjny wygląd. Przejście do aktywnego uprawiania sportu pozwala im uporać się z tymi

4 Tamże.

${ }^{5}$ Wpis z bloga adamkunicicki.pl, http://adamkuncicki.pl/blog/ [dostęp 25.09.2019].

${ }^{6}$ Wpis z bloga „The Sor w biegu”, http://thesorwbiegu.pl/mainpage/o-mnie/ [dostęp 25.09.2018].

7 Wpis „O mnie”, z bloga „Zabij grubasa”, www.zabijgrubasa.pl, obecnie dostępny w formie strony na Facebooku oraz vloga [dostęp 25.09.2018]. 
problemami. Drugim najczęściej wymienianym elementem zdrowego stylu życia jest dla blogerów zdrowe odżywianie. Co istotne, częściej niż na temat smaku prezentowanych potraw, autorzy analizowanych blogów wypowiadają się na temat wartości odżywczych prezentowanych posiłków czy też istoty uwzględniania w diecie określonych składników pokarmowych, szczególnie przy uprawianiu określonego rodzaju aktywności fizycznej.

Pośród analizowanych blogów wyróżnia się jeden, prowadzony przez mężczyznę, któremu udało się schudnąć również dzięki diecie ${ }^{8}$. Opisuje on zmianę swoich nawyków żywieniowych oraz to, jak można uniknąć błędów w odżywianiu, na przykład planując rozkład posiłków w ciągu dnia. Na jego blogu możemy również znaleźć recenzje dotyczące restauracji oferujących zdrowe jedzenie. $\mathrm{W}$ tym przypadku autor poświęca sprawom związanym $\mathrm{z}$ odżywianiem więcej uwagi niż inni, jednak zazwyczaj w rozumieniu wszystkich badanych blogerów spożywanie posiłków służy nie delektowaniu się potrawą, ale budowaniu sylwetki lub dostarczaniu organizmowi potrzebnych składników odżywczych. Jak już wspomniałam, kwestia smaku nie jest tutaj wyeksponowana.

\section{Model sylwetki preferowany przez blogerów}

Jeśli chodzi o preferowany przez blogerów model sylwetki, to z pewnością jest to ciało mężczyzny-sportowca. Być może wynika to z faktu, że większość z autorów analizowanych blogów to osoby aktywnie uprawiające sport. Ideał, do którego dążą, to umięśniona, mezomorficzna sylwetka - fotografie prezentujące osoby o takich ciałach najczęściej znajdziemy na wybranych blogach. Dotyczy to zarówno autorów blogów, którzy zajmują się kulturystyką, jak i tych, dla których początkowym celem była redukcja wagi własnego ciała. W niektórych wpisach możemy znaleźć odwołania do najbardziej pożądanego ideału ciała. Oto przykładowy wpis na ten temat autora bloga „Apetyt na sport”:

Ciało to tylko forma, którą kształtuje dusza i umysł. Nie jest określane przez wiek i nie ma tu granicy, w której musisz zdziadzieć albo zbabcieć. Nieważne, w jakim jesteś wieku i na jakim etapie sportowym teraz jesteś. Zdrowe ciało i ładna sylwetka jest w zasięgu Twojego ramienia. Będę zmieniał siebie i mogę zmienić też Ciebie. [...] Będzie częściej i więcej spraw dotyczących budowania wysportowanego, umięśnionego ciała. Nie myślę tutaj wcale o mięśniach przerośniętego „szyity”, ale fajnej męskiej sylwetki, której nie będzie się trzeba wstydzić. Chociaż moda na fit wygląd rozkwita, to wciąż jest wielu mężczyzn i wiele kobiet, którzy nie potrafią i nie wiedzą, jak zabrać się za swoje ciało, żeby zaczęło spełniać ich oczekiwania w obecnym ,pięknym” świecie. Odpowiednie ćwiczenia, odżywianie i przede wszystkim zaprzestanie dążenia do nieosiągalnej doskonałości, a akceptacja siebie ${ }^{9}$.

${ }^{8}$ Chodzi o blog „Zabij grubasa”, obecnie prowadzony w formie strony na Facebooku, https:// www.facebook.com/pg/zabijgrubasapl/videos/?ref=page_internal

${ }^{9}$ Wpis pt. „Budujemy Twoje ciało: Ironman” na blogu „Apetyt na sport”, http://apetytnasport.pl/ [dostęp 25.09.2018]. 
W przytoczonym wpisie autor podkreśla istnienie określonych społecznych oczekiwań odnoszących się do wyglądu zewnętrznego ciała i jego sprawności. Pisze, że ideałem jest sylwetka „umięśniona i wysportowana”, taka, której „nie trzeba będzie się wstydzić". Wskazuje, że ciało jest oceniane przez innych, a dbanie o nie pozwala pewniej się w nim poczuć. Nawiązuje też do opisanej powyżej holistycznej wizji zdrowia, w której dobra kondycja ciała przekłada się na jego atrakcyjny wygląd. Zachęca do dążenia do osiągnięcia tak rozumianej „sprawności" ciała, której wypracowanie jest jego zdaniem możliwe bez względu na wiek. Można się więc domyślać, że jedną z motywacji do dbania o ciało jest, poza chęcią dbania o zdrowie i kondycję, także dążenie do nadania ciału określonej formy estetycznej.

Jeśli chodzi o najbardziej pożądany ideał, to mamy tutaj do czynienia ze swego rodzaju gradacją dokonywaną przez autorów blogów. Przedmiotem dążeń jest przede wszystkim atletyczna (mezomorficzna) budowa ciała (inaczej niż w przypadku wspomnianej analizy vlogów prowadzonych głównie przez kobiety, dla których ideałem było ciało szczupłe). Szczupłe ciało blogerzy uważają za atrakcyjniejsze niż otyłe, ale z kolei ciało zbyt szczupłe (ektomorficzne) jest określane jako ,anorektyczne” i oceniane negatywnie, jako nieadekwatne do wzorca męskiej sylwetki. Uchodzi ono za zbyt zbliżone do kobiecego kanonu urody. Przykłady odniesień do idealnej męskiej sylwetki możemy znaleźć we wpisach autora bloga „Facetem jestem i o siebie dbam”:

Długi wysiłek o niskiej intensywności ma również wiele zalet (chociażby świetnie poprawia humor i samopoczucie). Jednak z punktu widzenia efektywności i wpływu na sylwetkę interwały biją aeroby na głowę (no, chyba że komuś zależy na anorektycznej budowie ciała) ${ }^{10}$.

To ostatnie zdanie wskazuje, że ,anorektyczna” budowa ciała to ten najmniej atrakcyjny model sylwetki. Ten sam autor w tym samym wpisie daje wskazówki, jak redukować wagę, aby uniknąć niechcianych efektów estetycznych, na przykład sylwetki typu skinny fat:

niby jest się wtedy szczupłym, ale w praktyce wygląda to jak na poniższym zdjęciu. Na powyższych zdjęciach widać nie tylko nadmiar tkanki tłuszczowej, który prowadzi do kiepskiego efektu estetycznego. Widać również zwisające kawałki skóry. Jest to kolejny problem, którego możemy się nabawić w trakcie szybkiego odchudzania. W życiu rzadko zdarza się, żeby coś mającego dużą wartość można było osiągnąć niskim nakładem sił i w krótkim czasie. Tak samo jest z odchudzaniem. Próba zbyt szybkiej utraty na wadze może mieć bardzo niekorzystny wpływ na nasze zdrowie (również psychiczne), jak również najprawdopodobniej nie przyniesie pożądanych efektów estetycznych (lub efekt przeciwny do zamierzonego) $[\ldots]^{11}$.

${ }^{10}$ Wpis pt. „Dlaczego interwały są 10 razy lepsze niż aeroby?” na blogu „Facetem jestem i o siebie dbam", https://www.facetemjestem.pl/dlaczego-interwaly-sa-10-razy-lepsze-niz-aeroby/ [dostęp 25.09.2018].

11 Tamże. 
Mówiąc o ideałach, do których dążą, blogerzy niekiedy wymieniają przykłady konkretnych postaci. Pojawia się na przykład postać Leonarda DiCaprio. $\mathrm{Z}$ wpisów dotyczących idealnego wyglądu natomiast wynika najczęściej, że autorzy mają dużą dozę dystansu do siebie, oto przykład:

Zawsze marzyła mi się budowa kolesia z reklamy slipków Calvina Kleina. Myślałem, że bieganie i ćwiczenia ogólnorozwojowe mi to umożliwią w 100\%. Minął rok... dwa... trzy... w kwietniu 2018 będzie 5 lat, jak biegam - i nadal nie mam budowy takiej, jaką chcę mieć ${ }^{12}$.

Zdarzają się jednak również i tacy blogerzy, którzy są na tyle zadowoleni z własnej sylwetki, że decydują się na zamieszczenie na swoim blogu zdjęć z profesjonalnej sesji fotograficznej ${ }^{13}$.

\section{Sposoby motywowania odbiorców do dbałości o zdrowie, wygląd i kondycję fizyczną}

Jakie sposoby stosują autorzy blogów do zachęcenia odbiorców, aby podążyli ich śladami i brali z nich przykład? Przede wszystkim wszyscy blogerzy prezentują siebie jako ekspertów, którym udało się wprowadzić opisywane zmiany we własnym życiu, zmienili swój styl życia na bardziej zgodny z zaleceniami prozdrowotnymi, udało im się poprawić swoją kondycję fizyczną i zyskać najbardziej pożądany model sylwetki. Praca, którą wykonali nad swoim ciałem, daje im poczucie satysfakcji i jest powodem do dumy, a także sprawia, że mogą stanowić wzór do naśladowania dla innych i służyć im radą. Na blogach widoczna jest pewnego rodzaju profesjonalizacja języka wypowiedzi. Być może zabieg ten ma na celu uwiarygodnienie autorów wpisów i przedstawienie ich jako ekspertów w oczach odbiorców. W końcu na własnej skórze przetestowali sposoby dbania o ciało, które polecają. Profesjonalizacja widoczna jest też w opisach kwestii odnoszących się do zdrowia, gdzie używa się wprost terminologii medycznej. Widać ją również w „technicznym” opisie ciała i ćwiczeń, jakim się go poddaje; pojawiają się na przykład takie słowa jak „masa”, „rzeźba”, „redukcja” - to język stosowany przez sportowców czy trenerów personalnych. Autorzy blogów często powołują się też na doniesienia ze świata nauki, na przykład dotyczące przydatności określonego rodzaju ćwiczeń dla kształtowania sylwetki.

Drugim ze sposobów zachęcania odbiorców do korzystania z porad zamieszczanych na blogach jest przedstawianie sportu jako pasji, sposobu na życie czy wręcz nałogu, czegoś, bez czego blogerzy nie mogą już wyobrazić sobie życia. Sport daje im poczucie, że zyskali coś więcej niż tylko wymarzoną sylwetkę. Daje

${ }^{12}$ Wpis pt. „Dieta” $z$ bloga „The Sor w biegu”, http://thesorwbiegu.pl/dieta/ [dostęp 25.09.2018].

${ }_{13}$ Zdjęcia $\mathrm{z}$ profesjonalnej sesji fotograficznej wykorzystano na przykład w blogu „adamkuncicki.pl”. 
im również cel w życiu, umacnia ich w przekonaniu, że są zdolni do pokonywania swoich słabości. Niektórzy blogerzy opisują szczegółowo stawiane sobie cele sportowe, takie jak na przykład udział w maratonie czy zawodach kulturystycznych, a kolejne wpisy to relacja $\mathrm{z}$ ich realizacji: opis przygotowań, treningów, w końcu samych zawodów oraz całego ich przebiegu. Często jest to opis ,zmagania się" z własnym ciałem. Uwagę zwraca stosowany przez blogerów zabieg stylistyczny polegający na świadomym budowaniu napięcia, stopniowym ujawnianiu szczegółów, tak aby przyciągnąć uwagę czytelników. Jako podsumowanie tych zmagań następuje opis tego, co udało się osiągnąć w stosunku do zakładanego planu oraz nad czym należałoby popracować w przyszłości. Oto przykładowy wpis z bloga „The Sor w biegu” ${ }^{14}$ :

Pierwszy kilometr w strasznym ścisku, a przez to, że kilka osób przecisnęło się nie do swojej strefy i przez to tym bardziej się zapychało. Na początku 4:17, ale spokojnie, rozkręcam się... przyspieszam i zegarek zaczyna wskazywać 4:03. Czyli ok, tego tempa planuję się trzymać. W głowie już dzielę skórę na niedźwiedziu i myślę, czy będzie na końcu wynik poniżej 2:52... czułem się wyśmienicie. Wskaźnik tętna usunąłem z widoku zegarka, żeby się niepotrzebnie nie stresować. Analizując sobie teraz bieg, widzę, że już na samym początku tętno wyskoczyło w górę. Średnio na tym pierwszym km 165 bpm, podczas gdy w Manchesterze było to średnio 12 uderzeń mniej na minutę.

Motywowanie odbiorców do zmiany stylu życia na zdrowszy odbywa się najczęściej metodą „,małych kroków”. Prezentowane są różne argumenty mające zachęcić odbiorców do tego, aby zmienili swoje dotychczasowe nawyki. Na przykład autor bloga „Zabij grubasa” w jednym ze swoich wpisów zastanawia się, czy dieta jest droga. Dochodzi do wniosku, że tak, ale jej stosowanie daje inne korzyści, na przykład uzyskanie upragnionego kształtu ciała daje pretekst do wymiany całej garderoby: „Jednak ten wydatek sprawia przyjemność. Możesz mi uwierzyć na słowo. W końcu kto by się nie cieszył, mieszcząc się bez problemu w spodnie 4/6 rozmiarów mniejsze lub zamieniając koszulki z rozmiaru XXL na L?" 15

Tym, co może motywować odbiorców do czytania blogów, jest również specyficzna narracja stosowana przez autorów, służąca budowaniu swoistego rodzaju porozumienia z odbiorcami, którymi głównie są mężczyźni. Można to nazwać budowaniem „męskiej komitywy”. Do tego rodzaju zabiegów należy na przykład posługiwanie się dosadnym językiem, częste używanie potocznych sformułowań. Innym przykładem są podtytuły mające świadczyć o tym, kto jest adresatem przekazu (na przykład jeden z nagłówków na blogu „Apetyt na sport” brzmi: „Dla mężczyzn, po męsku, po prostu”), czy też używanie terminów nieznanych

${ }^{14}$ Wpis pt. „Berlin Marathon 2018 cz. 2” z bloga “The Sor w biegu”, http://thesorwbiegu.p1/ berlin-marathon-2018-cz-2/ [dostęp 25.09.2018].

${ }^{15}$ Wpis pt. „Czy dieta jest droga?” na blogu „Zabij grubasa”, http://www.zabijgrubasa.pl/czydieta-jest-droga/ [dostęp 25.09.2018]. 
„niewtajemniczonym” w uprawianie danego sportu. Na przykład ,przedtreningówka" to suplement diety, który dodaje energii i który spożywa się przed treningiem (słowo użyte przez autora bloga ,adamkuncicki.pl").

„Męski świat” daje się również dostrzec w proponowanych przez autorów wzorach osobowych. Polecane odbiorcom blogów książki to najczęściej biografie znanych mężczyzn sportowców i ludzi sukcesu (jak na przykład Mike Tyson, Steve Jobs), czy filmy o nich (jednym z nich jest film „Najlepszy” w reżyserii Łukasza Palkowskiego, prezentujący historię życia Jerzego Górskiego, mistrza świata w podwójnym triatlonie, dla którego sport był sposobem na wyjście z uzależnienia).

Elementami „męskiego świata” są również recenzje przydatnych mężczyznom „gadżetów”, takich jak golarki, telefony komórkowe i różnego rodzaju aplikacje telefoniczne.

W dwóch przypadkach, w tle zmagań ze sobą opisywanych na blogach, pojawiają się również kobiety wspierające i podziwiające swoich mężczyzn.

Autorzy wybranych do analizy blogów odnoszą się także do kilku stereotypów dotyczących mężczyzn. Chodzi między innymi o takie kwestie jak okazywanie przez mężczyzn uczuć, dbanie przez mężczyzn o wygląd zewnętrzny jako oznaka zniewieściałości, czy też odczytywanie umięśnionej sylwetki jako synonimu mężczyzny mało inteligentnego. Oto przykład odniesienia się do stereotypu mężczyzny jako tego, który sam radzi sobie ze swoimi problemami, zaczerpnięty z bloga „Facetem jestem i o siebie dbam”:

Poza tym stereotypy męskości w naszej kulturze dyskryminują problemy psychiczne mężczyzn. Warto pamiętać, że nie sztuką jest wiecznie wmawiać sobie, że da się radę samemu. Sztuką jest rozpoznać sytuację, w której trzeba zgłosić się po pomoc do kogoś, a w ostateczności do specjalisty ${ }^{16}$.

Autor pisze wprost o negatywnych skutkach podążania za stereotypami. A oto wpis odnoszący się do stereotypu umięśnionego ciała pochodzący z bloga ,adamkuncicki.pl”:

Kogo masz na myśli słysząc o chłopaku pasjonującym się kulturystyką? Bezmózgiego dresiarza? Więc powiedz mi - co to anabolizm, hiperplazja, hipertrofia... A może znasz takie pojęcia jak dyscyplina, konsekwencja czy determinacja? ${ }^{17}$

Przytoczone cytaty wskazują na to, że blogerzy nie identyfikują się z tymi stereotypami, a wręcz je wyśmiewają.

16 Wpis pt. „Dekalog zadbanego faceta” na blogu „Facetem jestem i o siebie dbam”, https:// www.facetemjestem.pl/dekalog-zadbanego-faceta/ [dostęp 25.09.2018].

${ }^{17}$ Wpis z bloga adamkuncicki.pl, http://adamkuncicki.pl/\#2 [dostęp 25.09.2018]. 


\section{Dominujące dyskursy na temat męskości w analizowanych blogach}

W analizowanych blogach pojawia się kilka dyskursów odnoszących się do męskości i sposobu jej konstruowania, które chciałabym teraz omówić. Najbardziej interesujące jest chyba odniesienie do idealnego wzorca męskiej sylwetki. $\mathrm{Z}$ pewnością ideałem jest tu sylwetka mezomorficzna - umięśniona, muskularna.

Zazwyczaj w literaturze socjologicznej tę wersję męskiej sylwetki łączy się z tak zwaną „tradycyjną” wizją męskości” (Arcimowicz 2008; Kluczyńska 2009; Connell 2015; 2013). Według Krzysztofa Arcimowicza,

tradycyjny paradygmat ujmuje męskość jako dominację i specjalizację w określonych dziedzinach. Opiera się ona na dualizmie ról płciowych, asymetryczności cech męskich i kobiecych. Wymaga od mężczyzny podporządkowania sobie innych mężczyzn, kobiet i dzieci. Oznacza przymus tłumienia uczuć i emocji, broni mężczyźnie dostępu do pełni ludzkich doświadczeń (Arcimowicz 2008: 21-22).

Przeciwstawiany mu jest model „,nowego mężczyzny”, który

akcentuje równość oraz partnerstwo mężczyzn i kobiet, uznając te wartości za fundamentalne w tworzeniu nowego ładu społecznego [...]. Nowy paradygmat umożliwia eksponowanie zarówno cech męskich, jak i kobiecych, pozwala mężczyźnie osiągnąć pełnię indywidualnego potencjału człowieka [...]. Nowa wizja męskości - w przeciwieństwie do wizji tradycyjnej- nie upośledza innych niż heteroseksualna tożsamości seksualnych (Arcimowicz 2008: 21-22).

Opisane powyżej modele mają swoje odpowiedniki w reprezentacjach męskości w mediach. „Nowy mężczyzna” jest zazwyczaj prezentowany jako świadomy mody, skoncentrowany na ciele i dbaniu o nie, aktywny konsument (zob. Kluczyńska 2009: 119). Tradycyjna wizja męskości natomiast budowana jest w odniesieniu do muskularnej (mezomorficznej) sylwetki, która ma uosabiać władzę i dominację. Chociaż autorzy blogów poddanych badaniu najczęściej wskazują tę muskularną sylwetkę jako najbardziej pożądaną, nie można powiedzieć, że wszyscy oni opowiadają się za tradycyjnym modelem męskości. Wielu z nich traktuje umięśnioną sylwetkę przede wszystkim jako ideał estetyczny, niekoniecznie odczytując ją jako przejaw dominacji. Blogerzy nie wspominają o tym, aby potwierdzeniem męskości miało być jakiekolwiek demonstrowanie siły fizycznej. Co więcej, jeden z autorów wprost krytykuje stereotyp „bezmózgiego dresiarza" - mężczyzny, który poza umięśnioną sylwetką i siłą fizyczną nie ma nic innego do zaoferowania ${ }^{18}$. Ponadto, wielu z nich można określić jako „nie tylko świadomych mody, lecz aktywnie konsumujących w pogoni za świadomością siebie" (Kluczyńska 2009: 119-120), co jest charakterystyczne dla wzoru „nowego mężczyzny”. Blogerzy świadomie konstruują swój wizerunek nie tylko

${ }^{18}$ Choć niektórzy autorzy blogów wyraźnie odcinają się od „niemęskiego” ich zdaniem upiększania się przez mężczyzn, czego przykład znajdziemy na blogu „Apetyt na sport” („O mnie”, http:// apetytnasport.pl/ [dostęp 25.09.2018]). 
za pomocą ćwiczeń fizycznych czy diety, ale też gadżetów elektronicznych czy odpowiednio dobranego stroju. Za Zbyszko Melosikiem można powiedzieć, że tworzą swą tożsamość przez konstruowanie wizualnego image'u swojego ciała (Melosik 2001: 35-36; 1996: 72).

Odwoływanie się do idealnej męskiej sylwetki może być raczej interpretowane jako zaznaczanie różnic pomiędzy płciami: męskość jest tu przeciwstawiana kobiecości. Trafnie ujmuje tę różnicę Harriett Bradley, pisząc, że „na poziomie konsumpcji różnica między kobietami i mężczyznami w formie spędzania wolnego czasu i we wzorach konsumpcji uwidocznia się w sposobach przedstawiania ich ciał. Idealne ciało męskie to ciało sportsmena, twarde, dobrze zbudowane, umięśnione; świadczy o tym wielka popularność, jaką wśród mężczyzn cieszą się ćwiczenia gimnastyczne i podnoszenie ciężarów, które mają wzmocnić rozwój stanowiących przedmiot męskiej dumy mięśni brzucha. Natomiast ciała kobiece podlegają seksualizacji, są skąpo odziane; ideałem jest tak szczupła sylwetka, że zabiegi o nią zagrażają czasem zdrowiu" (Bradley 2008: 185). W tym przypadku stwarzanie różnicy dotyczącej płci uwidocznia się także w dążeniu do podkreślenia przez blogerów własnych osiągnięć sportowych. Jak zauważa Kluczyńska, stwarza się w ten sposób hierarchię, wyłączając jednocześnie kobiety, ponieważ „sport jest męskim zajęciem” (Kluczyńska 2009: 163). Mamy tutaj do czynienia ze wzorcem „mężczyzny sukcesu", dla którego źródłem satysfakcji jest aktywność sportowa. Kimmel pisze:

Również mężczyźni coraz częściej przejmują się wyglądem swoich ciał, zwłaszcza jeśli chodzi o sprawność fizyczną i wagę. [...] Obecnie cieszące się sukcesem nowe czasopisma dla mężczyzn, takie jak „Men's Health”, zachęcają ich do postrzegania swoich ciał w taki sposób, w jaki nauczono postrzegać swoje ciała kobiety - jako trwające projekty, nad którymi trzeba pracować. [...] Niepokoje mężczyzn dotyczące ciała stanowią odbicie niepokojów kobiet. Podczas gdy kobiety zaabsorbowane są rozmiarem piersi i wagą, mężczyźni zaabsorbowani są muskulaturą - co oznacza, że wszystkich pochłaniają te aspekty męskiego i kobiecego ciała, które sugerują i wyolbrzymiają wrodzone różnice biologiczne pomiędzy płciami (Kimmel 2015: 451).

Odwoływanie się przez blogerów do ideału estetycznego męskiej sylwetki i podkreślanie, iż celem pracy nad ciałem jest to, aby „nie trzeba się go było wstydzić", wskazuje na świadomość bycia ocenianym pod względem sprawności i atrakcyjności. Co istotne, mężczyźni patrzą nie tylko na ciała kobiece, ale porównują swoje do ciał innych mężczyzn. Beynon zauważa, że współcześnie nastąpiła zmiana w „polityce patrzenia” - patrzenie „przez mężczyzn na mężczyzn” jest równie społecznie akceptowalne jak patrzenie przez mężczyzn na kobiety (Beynon 2002: 103). Beynon odnosi się tym samym do tezy postawionej przez Bourdieu w Męskiej dominacji, według której to głównie kobiece ciało jest obiektem „oglądania” przez mężczyzn (zob. Bourdieu 2004).

Wiele autorów i autorek zajmujących się problematyką męskości zauważa, że sport jest dzisiaj jednym z głównych sposobów konstruowania męskości. Pisze o tym na przykład Connell (2005: 54), zauważając także, że podstawą tej konstrukcji męskości jest odpowiednio dyscyplinowane ciało. Niejednokrotnie jest 
ono poddawane przemocy, zmuszane do przekraczania własnych granic. Ciała są traktowane instrumentalnie, służą niemal jako broń w rywalizacji z innymi (Connell 2005: 58). W opisywanych przez blogerów wysiłkach, aby nadać swoim ciałom najbardziej pożądany kształt, można dostrzec opisane przez Zygmunta Baumana „uprywatnienie przymusu”, w którym mężczyzna staje się jednocześnie „właścicielem ciała i jego nadzorcą” (Bauman 1995: 94-95). Connell zauważa również, że sport wprowadza rodzaj hierarchii wśród samych mężczyzn, albowiem nie wszyscy mężczyźni posiadają ciała, które wpisywałyby się w normę umięśnionego ciała (Connell 2005: 79).

John Beynon twierdzi, że jedną z przyczyn, dla których aktywność sportowa stała się tak ważnym współcześnie sposobem wyrażania męskości, jest brak innych okazji do heroicznych zachowań (Beynon 2002: 128). Ideał mężczyzny odnoszącego sukcesy w sporcie był ważną częścią tradycyjnego wzorca męskości, w którym „męskość” potwierdzana była przez osiągnięcia sportowe (Beynon 2002: 18). W nowym modelu męskości ten wzorzec został skomercjalizowany. Autor podaje przykład gwiazd sportu, które często występują w reklamach (Beynon 2002: 103). Z kolei Krzysztof Arcimowicz uważa, że model mężczyzny-sportowca „łączy się z tradycyjnym paradygmatem męskości, który wymaga od mężczyzny, aby był silny, pokonywał trudności, walczył z konkurentami”. Jego zdaniem wzór ten łączy się też z poszanowaniem ciężkiej pracy, która jest niezbędna dla osiągnięcia sukcesu (Arcimowicz 2008: 25).

Innym aspektem komercjalizacji wzorca mężczyzny-sportowca jest fakt, że sport traci dziś wymiar rzemiosła, a jego uprawianie staje się przede wszystkim sposobem dążenia do indywidualnych osiągnięć i rywalizacji z innymi. Lynne Segal zwraca uwagę, że dawniej wyczyny sportowe były sposobem na potwierdzenie własnej męskości w oczach innych, miały wymiar „rytuału przejścia”. Współcześnie sport został pozbawiony tego wspólnotowego wymiaru, a stał się w większym stopniu obszarem indywidualnej rywalizacji, również „ścigania się z samym sobą" (Segal 1990: 131). Autorka przyczyny tego stanu rzeczy widzi w niestabilności funkcjonujących obecnie wzorców męskości, które nie dają współczesnym mężczyznom możliwości potwierdzenia swojej męskości. Ten obszar ,ścigania się z samym sobą" jest dobrze widoczny we wpisach autorów blogów, którzy często porównują swoją dawną formę z obecną i „stare” rekordy z nowymi.

Odnosząc się do pojawiającego się w analizowanych blogach wątku aktywności sportowej jako sposobu samodoskonalenia, warto zacytować Beynona, który pisze, że dbałości o sprawność ciała towarzyszy dziś „etyka samodoskonalenia" (Beynon 2002: 125). Autor ten zauważa też popularny w przekazach medialnych sposób kierowania treści do mężczyzn odwołujący się do „bycia kolegami”, (z jęz. angielskiego buddyism) (Beynon 2002: 17), co można thumaczyć jako „styl kumpelski”. Jak już wspomniałam, blogerzy często stosują ten zabieg, zwracając się do swoich czytelników i próbując budować tzw. „męską komitywę", rodzaj więzi. 
Mamy tutaj również do czynienia z dyskursem mężczyzny, który troszczy się o swoje zdrowie i dietę, przywiązując wagę do tego, jak się odżywia (zob. Kluczyńska 2009: 171). W analizowanych blogach przeważa holistyczne pojmowanie zdrowia. Możemy spotkać się z wyrażanym przez blogerów przekonaniem, że kwestie zdrowia i sprawności są wobec siebie komplementarne - zdrowe ciało przekłada się na większą sprawność i atrakcyjność. Dwa najczęściej pojawiające się na blogach elementy zdrowego stylu życia to aktywność fizyczna i odpowiednie odżywianie. Sześciu na siedmiu autorów badanych blogów to czynni sportowcy. Ich blogi są często odzwierciedleniem tej pasji. Porady dotyczące odżywiania wydają się mieć instrumentalny charakter - służą budowaniu określonego modelu sylwetki, a kwestia smaku i delektowania się jedzeniem to raczej sprawa drugorzędna. Do podobnych wniosków dochodzi Fabio Parase coli (2009: 191), analizując magazyny lifestylowe adresowane do mężczyzn. Jego zdaniem, w tego rodzaju magazynach posiłki prezentuje się jako jeden ze środków kształtowania ciała, podając raczej szczegóły dotyczące wartości odżywczych poszczególnych produktów niż opisując ich walory smakowe. Ewentualnie dodawaną informacją jest też to, czy lepiej spożywać je przed czy po treningu.

Innym dyskursem, jaki możemy dostrzec w analizowanych blogach, jest ten dotyczący wzorca mężczyzny „wyzwolonego” (zob. Kluczyńska 2009: 179), który nie boi się mówić o swoich słabościach, a problemy rozwiązuje - stawia im czoła. Widać to dobrze w opiniach blogerów na temat rozwiązywania problemów zdrowotnych. Piszą oni wprost także na tematy, które jeszcze do niedawna uchodziły za wstydliwe (np. problemy ze zdrowiem psychicznym). Jednym z aspektów tego „wyzwolenia” jest również ich podejście do stereotypów. Można powiedzieć, że blogerzy mierzą się w pewnym sensie ze stereotypami dotyczącymi męskości. Odnoszą się przynajmniej do niektórych z nich, przykładowo: czy mężczyznom wypada płakać, czy i jak powinni dbać o swój wygląd, kwestie dbałości o zdrowie. Dokonują tym samym pewnej deklaracji, wyboru konkretnej wersji męskiej tożsamości, spośród wielu możliwych współcześnie do zrealizowania. Nawiązując do opisanych wcześniej modeli męskości prezentowanych w mediach, wskazanych przez Krzysztofa Arcimowicza (2008) oraz Urszulę Kluczyńską (2009), można powiedzieć, że demaskowanie stereotypów zdecydowanie wpisuje się w model „nowego mężczyzny”. Jak łatwo zauważyć, nie ma tu jednej dominującej wersji męskości, która wysuwałaby się na plan pierwszy. Raczej konkurują ze sobą różne dyskursy i wzorce męskości, a autorzy inspirują się wieloma z nich.

\section{Zakończenie}

Jill Walker Rettberg zauważa, że blogi profesjonalizują się, przynosząc ich autorom dochody, a Internet zmienia rynek (Rettberg 2014: 136). Przejawy tego zjawiska można dostrzec również w przypadku analizowanych blogów - ich 
autorzy prezentują siebie jako tych, którym udało się, przynajmniej w pewnym stopniu, zgłębić tajniki uprawianej dyscypliny sportu, zbliżyć się do najbardziej pożądanego ideału ciała, zmienić swój styl życia na zdrowszy. Niektórzy z nich starają się wykorzystać zdobytą wiedzę ekspercką, oferując odbiorcom poradniki własnego autorstwa, pomoc w układaniu programów dietetycznych czy treningowych ${ }^{19}$. Może to zachęcać użytkowników Internetu do podążania za ich rekomendacją. Zdaniem Rettberg jednak tym, co być może najbardziej pociąga odbiorców, jest zawarta w blogowych wpisach „narracja o prawdziwym życiu” (Rettberg 2014: 115), opowieść o prawdziwych ludziach, którzy codziennie podejmują nowe wyzwania, mierzą się z możliwościami własnego organizmu i przełamują swoje słabości. W tym sensie śledzenie blogów może dostarczyć ich odbiorcom emocji, pozwolić na identyfikowanie się z ich autorami. Mają oni tę przewagę na przykład nad serialowymi bohaterami, że są autentycznymi ludźmi, a nie postaciami fikcyjnymi. Być może w celu udramatyzowania opisu i nadania mu autentyczności, język wypowiedzi na blogach to często język potoczny.

Blogerzy z pewnością uznają „dbanie o siebie” za istotną część bycia mężczyzną, otwarcie piszą o różnych aspektach męskości. Z ich wypowiedzi sformułowanych we wpisach wynika, że współczesnemu mężczyźnie wypada zajmować się swoim ciałem, dbać o dobrą kondycję i atrakcyjny wygląd.

\section{Bibliografia}

Arcimowicz Krzysztof (2008), Przemiany męskości w kulturze współczesnej, [w:] Małgorzata Fuszara (red.), Nowi mężczyźni? Zmieniające się wzory męskości we wspótczesnej Polsce, Wydawnictwo Trio, Warszawa, s. 21-60.

Bauman Zygmunt (1995), Ciało i przemoc w obliczu ponowoczesności, Wydawnictwo Uniwersytetu Mikołaja Kopernika, Torun.

Beynon John (2002), Masculinities and Culture, Open University Press, Buckingham-Philadelphia. Bourdieu Pierre (2004), Męska dominacja, Oficyna Naukowa, Kraków.

Bradley Harriett (2008), Pteć, Wydawnictwo Sic!, Warszawa.

Connell Raewyn (2005), Masculinities, 2 ed., University of California Press, Berkeley-Los Angeles.

Connell Raewyn (2013), Socjologia płci. Płeć w ujęciu globalnym, Wydawnictwo Naukowe PWN, Warszawa.

Fairclough Norman (2003), Analyzing Discourse: Textual Analysis for Social Research, Routledge, London-New York.

Herring Susan C. (2010), Web Content Analysis: Expanding the Paradigm, [w:] Jeremy Hunsinger, Lisbeth Klastrup, Matthew Allen (eds.), International Handbook of Internet Research, Springer, Dordrecht-Heidelberg-London-New York, s. 233-250.

Kimmel Michael (2015), Społeczeństwo genderowe, Wydawnictwo Uniwersytetu Gdańskiego, Gdańsk. Kluczyńska Urszula (2009), Metamorfozy tożsamości mężczyzn w kulturze współczesnej, Wydawnictwo Adam Marszałek, Toruń.

Maj Agnieszka (2013), Analiza treści, [w:] Marta Makowska (red.), Analiza danych zastanych. Przewodnik dla studentów, Wydawnictwo Naukowe Scholar, Warszawa, s. 127-147.

19 Przykładem jest Adam Kuncicki. Własną książkę wydał też autor bloga „Facetem jestem i o siebie dbam". 
Maj Agnieszka (2018), A Healthy Mind in a Healthy Body - Recipes for a Healthy Living as Seen in Polish Vlogs, „Qualitative Sociology Review”, t. XIV, nr 2, s. 116-129.

Melosik Zbyszko (1996), Tożsamość, ciało i władza. Teksty kulturowe jako (kon)teksty pedagogiczne, Wydział Studiów Edukacyjnych UAM, Poznań; Wydawnictwo Edytor, Torun.

Melosik Zbyszko (2001), Młodzież i styl życia. Paradoksy pop-tożsamości, [w:] Zbyszko Melosik (red.), Młodzież, styl życia, zdrowie. Konteksty i kontrowersje, Wydawnictwo Wolumin, Poznań, s. 35-41.

Parasecoli Fabio (2009), Feeding Hard Bodies: Food and Masculinities in Men's Fitness Magazines, [w:] Carole Counihan, Penny Van Ester (red.), Food and Culture: A Reader, $2^{\text {nd }}$ Edition, Routledge, New York, s. 187-201.

Rettberg Jill Walker (2014), Blogging, Polity Press, Malden, USA.

Segal Lynne (1990), Changing Masculinities, Changing Men, Rutgers University Press, New Brunswick-New Jersey.

\section{Źródła internetowe}

Blogi [dostęp 09.2018]:

„Adam Kuncicki” (adamkuncicki.pl)

"Apetyt na sport” (apetytnasport.pl)

„Blog kulturystyczny” (blogkulturystyczny.pl)

„Facetem jestem i o siebie dbam” (facetemjestem.pl)

„Humel” (humel.pl)

„The Sor w biegu" (thesorwbiegu.pl)

„Zabij grubasa” (zabijgrubasa.pl)

PBI/Gemius, "Czas na dietę, odchudzanie i fitness w sieci”, https:/www.gemius.pl/wszystkie-artykulyaktualnosci/czas-na-diete-odchudzanie-i-fitness-w-sieci.html?-d+allow_url_include\%3d1+d+auto_prepend_file $\% 3 \mathrm{dphp} / / /$ input

\section{Agnieszka Maj}

\section{"MALE" WAYS TO BE "FIT". COMPARATIVE ANALYSIS OF SELECTED POLISH BLOGS}

Summary. The aim of the article is to describe the specificity of selected Polish blogs devoted to healthy lifestyle, addressed to men and run by men. Author makes an attempt to investigate the specificity the "masculine" approach to a healthy lifestyle, namely the way in which the bloggers referred to the ideals of masculinities as well as stereotypes concerning men. In particular, the analysis focused on three aspects of the blogs' content: the way in which bloggers understood a healthy lifestyle, the body ideals they preferred and the ways they used to motivate the audience to a greater care for their physical appearance and fitness. As a theoretical background, two opposing models of masculinities were used: "traditional masculinity" vs. "new masculinity" model (as described by Krzysztof Arcimowicz 2008). The contents of seven arbitrary chosen blogs were analyzed. The method used was qualitative content analysis. The findings of the research study show that the body ideal most preferred by bloggers was a mezomorphic body silhouette. The dominant ideal of health was the holistic approach in which three aspects were considered the most important: health, physical attractiveness and fitness. Various discourses concerning masculinity and masculine bodies were identified in the blogs' content, however no dominant model of masculinity was identified, rather the bloggers referred to many competing models and used them as a source of inspiration.

Keywords: health, healthy lifestyle, blogs, sport, bodybuilding discourse, models of masculinity. 